\title{
REVIEW
}

\section{Analysis of Tumor Biology to Advance Cancer Health Disparity Research}

\author{
Cheryl J. Smith, Tsion Z. Minas, and Stefan Ambs
}

From the Laboratory of Human Carcinogenesis, Center of Cancer Research, National Cancer Institute, National Institutes of Health, Bethesda, Maryland

\author{
Accepted for publication \\ June 29, 2017. \\ Address correspondence to \\ Stefan Ambs, Ph.D., M.P.H., \\ Laboratory of Human Carcino- \\ genesis, National Cancer Insti- \\ tute, Bldg 37/Room 3050B, \\ Bethesda, MD 20892-4258. \\ E-mail: ambss@mail.nih.gov.
}

\begin{abstract}
Cancer mortality rates in the United States continue to decline. Reductions in tobacco use, uptake of preventive measures, adoption of early detection methods, and better treatments have resulted in improved cancer outcomes for men and women. Despite this progress, some population groups continue to experience an excessive cancer burden when compared with other population groups. One of the most prominent cancer health disparities exists in prostate cancer. Prostate cancer mortality rates are highest among men of African ancestry when compared with other men, both in the United States and globally. This disparity and other cancer health disparities are largely explained by differences in access to health care, diet, lifestyle, cultural barriers, and disparate exposures to carcinogens and pathogens. Dietary and lifestyle factors, pathogens, and ancestry-related factors can modify tumor biology and induce a more aggressive disease. There are numerous examples of how environmental exposures, like tobacco, chronic stress, or dietary factors, induce an adverse tumor biology, leading to a more aggressive disease and decreased patient survival. Because of population differences in the exposure to these risk factors, they can be the cause of cancer disparities. In this review, we will summarize recent advances in our understanding of prostate and breast cancer disparities in the United States and discuss how the analysis of tumor biology can advance health disparity research. (Am J Pathol 2018, 188: 304-316; https://doi.org/10.1016/j.ajpath.2017.06.019)
\end{abstract}

Cancer mortality rates in the United States have been declining since the 1990 s because of reduced tobacco use among adults, more widespread cancer screening and testing, and improved cancer therapies. ${ }^{1,2}$ Despite this progress, disparities continue to persist across different racial and ethnic groups. ${ }^{2,3}$ In the United States, African Americans disproportionately bear the cancer burden and have the highest death rates for many cancer types of any racial or ethnic group. 4

Breast cancer and prostate cancer are the two most common invasive cancers in women and men, respectively. Advancements in detection and cancer therapy have improved cancer care and disease outcomes for these two cancer types. Although incidence rates for prostate cancer are decreasing in the United States, they are still increasing in many parts of the world. The latter can be attributed to population aging and adaptation of a Western lifestyle. Likewise, breast cancer incidence rates are also increasing globally. In the United
States, these rates have been stable for many years; however, for African-American women, breast cancer incidence increased $(0.7 \%$ per year), whereas the disease incidence decreased (1.0\% per year) among European-American women between 2000 and 2009. Although breast cancer mortality has decreased annually by an average of $2 \%$, likely because of improved diagnosis and treatment, African-American women still have the highest mortality when compared with other racial and ethnic groups. ${ }^{4-6}$ The reasons for the observed disparities are multifactorial and include access to health care, socioeconomic status, health literacy, and discrimination.

Supported by the Intramural Research Program of the NIH, the National Cancer Institute, and the Center for Cancer Research grants ZIA BC 010499, ZIA BC 010624, and ZIA BC 010887.

Disclosures: None declared.

This article is part of a review series on understanding the complex role of race in cancer health disparities. 
Nonetheless, these socioeconomic and sociobehavioral factors do not fully explain these health disparities. Therefore, health disparity research has begun to explore biological factors. This approach is further supported by the observation that disease characteristics of prostate and breast cancer show significant geographic and ethnic variations. ${ }^{7,8}$ Research efforts have begun to concentrate on molecular mechanisms in tumor biology and ancestry-related aspects that may contribute to cancer disparities (Figure 1). This review will focus on bringing to light the molecular and epidemiologic work that has gone into understanding the tumor biological differences that may contribute to cancer health disparities.

\section{Survival Health Disparities in Breast and Prostate Cancer in the United States}

\section{Survival Health Disparities in Prostate Cancer}

Prostate cancer is the second leading cause of cancer-related deaths in US men and exhibits a pronounced racial disparity. Well-established risk factors for the disease are age, family history of the disease, race/ethnicity, and inherited genetic factors that include approximately 100 disease susceptibility loci that are known. ${ }^{9}$ African-American men have a mortality rate more than double that of European-American men, in part because of their increased risk of developing the disease. Surveillance, epidemiology, and end results data for the period from 1975 to 2012 show that African-American men have an earlier mean age of a prostate cancer diagnosis (69.1 versus 71.1 years) and a shorter mean survival period (44.4 versus 48.4 months) when compared with EuropeanAmerican men. ${ }^{10}$ This survival disparity has been observed for $>20$ years, despite the approximately equal prevalence of prostate-specific antigen testing among African-American and European-American men. ${ }^{11,12}$ The higher disease mortality of African-American men is caused by multiple factors, including access to care, biological/genetic differences, geography, and patient characteristics and behaviors. ${ }^{12}$ Interestingly, men of West-African ancestry from the Caribbean and South America exhibit incidence and mortality rates similar to African-American men, suggesting a possible ancestral basis for some of these common outcomes. ${ }^{13}$

The higher mortality rates among African-American men may also occur because these men are prone to a more aggressive type of prostate cancer. A study conducted by Tyson and Castle ${ }^{14}$ examined racial disparities in survival for patients with clinically localized prostate cancer. Even though the investigators adjusted for clinical and socioeconomic factors, African-American men still had the worst survival compared with European-American, Hispanic, or Asian men. Powell et $\mathrm{al}^{15}$ analyzed prostate autopsy material from 1056 African-American and European-American men who did not have a prior diagnosis of prostate cancer. They compared autopsy findings with results from the analysis of resected tumors. Although the disease presentation was similar between the two patient groups at the subclinical stage, among the patients with clinically detected prostate tumors, African-American men tended to have a more aggressive disease than European-American men. This finding is consistent with an accelerated disease progression in African-American men, indicating that differences in tumor biology may exist between the two patient groups.

\section{Survival Health Disparities in Breast Cancer}

The US health disparity in breast cancer presents itself different from the disparity in prostate cancer because it is mostly a survival health disparity, with a disproportionately
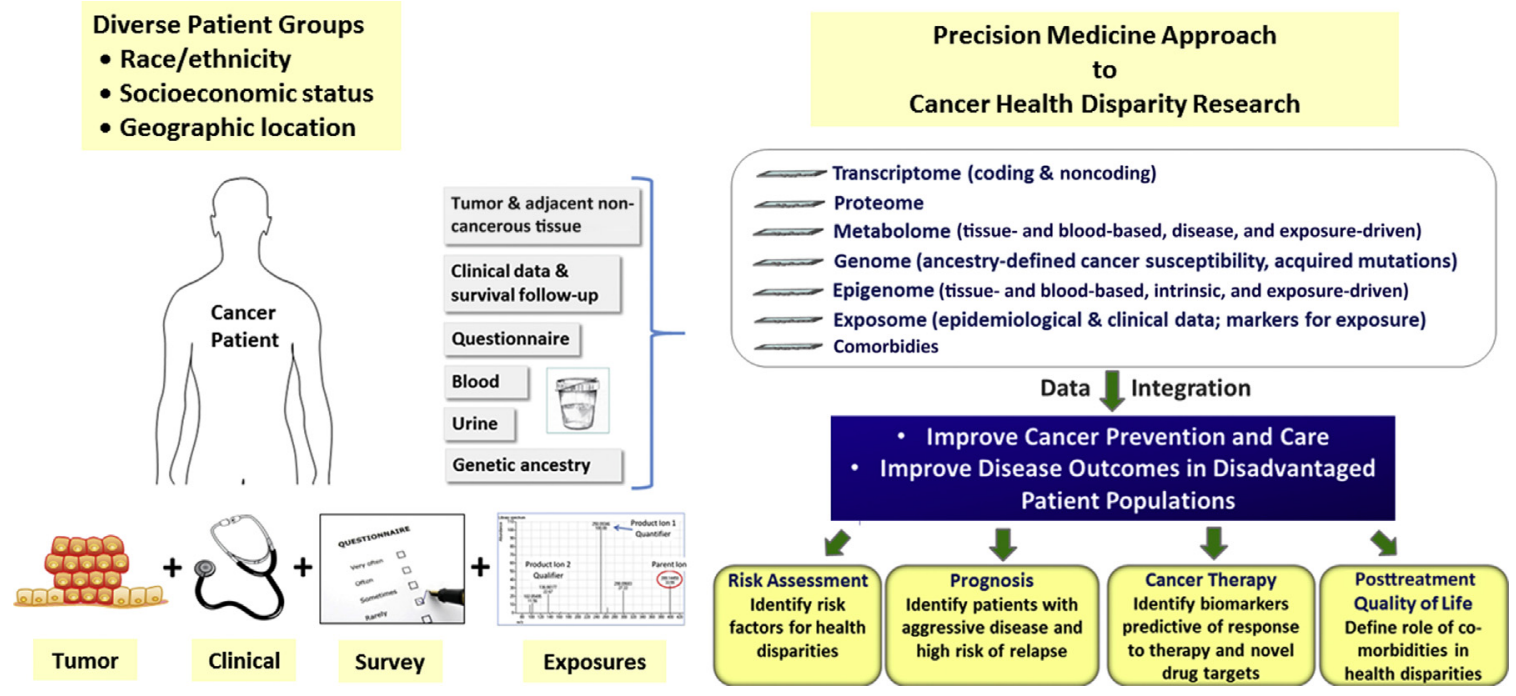

Figure 1 Analysis of tumor biology to advance cancer health disparity research. A precision medicine approach is shown for cancer health disparity research that uses an integrated analysis of tumor tissues and other biospecimens, clinical data, survey and exposure data (eg, diet and lifestyle, environmental exposures, family and sexual history, occupation, social isolation, and discrimination), and patient characteristics (eg, socioeconomic status, body mass index, comorbidities, and genetic ancestry). 
high mortality among African-American, Latina, and Native American women. ${ }^{6}$ Although advancements in cancer treatment, screening, and diagnosis are helping women overall, breast cancer incidence rates in African-American women are increasing. Currently, the 5-year relative survival rate is $80 \%$ for African-American women compared with $91 \%$ among European-American women. ${ }^{4}$ It is believed that nonbiological and biological factors play a major role in this survival disparity. ${ }^{16}$ Nonbiological factors include socioeconomic factors, access to health care, cultural factors, and comorbidities.

A poorer survival of African-American breast cancer patients has also been observed in equal access health care systems and clinical trial settings. ${ }^{17,18}$ It was thought that the increased prevalence of early-onset estrogen receptor (ER)-negative tumors and basal-like/triple-negative tumors in women of African ancestry is largely responsible for the excessive mortality. Although this argument is plausible, one has to be cautious because the breast cancer survival disparity occurs irrespective of the tumor's ER status. ${ }^{19}$ A study by Hershman et $\mathrm{al}^{20}$ found that, after controlling for stage, demographics, socioeconomic variables, tumor characteristics, and treatment factors, an excessive mortality remained among both pre and postmenopausal African-American women who were diagnosed with early-stage breast cancer. These findings are consistent with the more recent observations by Silber et al. ${ }^{16}$ Therefore, still poorly understood molecular and genetic differences in tumor biology may promote a more aggressive disease in women of African descent. A better understanding of these biological factors is critical for addressing the high disease mortality observed in AfricanAmerican women.

\section{Biological Determinants of Cancer Health Disparities}

Observations from migration studies that immigrants tend to acquire cancer rates of their new home country within two generations indicate the importance of modifiable exposures as major risk factors for common cancers in the United States. ${ }^{21,22}$ Yet, breast and prostate tumors tend to be more aggressive at diagnosis in African Americans than they are in European-Americans. This disparity has not been eliminated with the equal use of cancer screening and has generated a heightened interest in understanding the biology of these tumors. Subsequently, this research led to the discovery of differences in both genetic predisposition to cancer and molecular subtypes between these population groups, which we will discuss later in separate sections. Apart from these observations, additional differences in the tumor biology between African-American and EuropeanAmerican patients were described by investigators who used gene expression, mutational, and immunohistochemical analyses of tumors.
In prostate cancer, the epidermal growth factor receptor was found to be more commonly expressed in tumors from African-American patients when compared with EuropeanAmerican patients. ${ }^{23}$ Using a differential display analysis, a novel prostate-specific gene, termed PCGEMI, was identified that encodes a long noncoding RNA with a cell growth-promoting function. ${ }^{24}$ This transcript is most highly expressed in prostate tumors of African-American patients. Others described ZBTB33 (alias KAISO) and motor neuron and pancreas homeobox 1 (MNX1) as oncogenically up-regulated genes in tumors of these patients. KAISO is regulated by epidermal growth factor receptor signaling and is a key transcription factor that induces epithelial-to-mesenchymal transition, whereas MNX1 regulates lipid synthesis. ${ }^{25,26}$ Last, a recurrent deletion on chromosome 3q13.31 was found to occur in prostate tumors of African-American patients that associates with the loss of the ZBTB20-LSAMP locus and with an aggressive disease. ${ }^{27}$

Few studies have examined the biology of breast tumors in African-American women beyond the concept of molecular subtypes. Several used gene expression profiling to study the biology. ${ }^{28,29} \mathrm{~A}$ race/ethnicity-associated gene signature of poor outcome was described for luminal A breast tumors. ${ }^{30}$ This signature comprises six genes that are differentially expressed between African-American and EuropeanAmerican patients. Terunuma et $\mathrm{al}^{31}$ reported a high prevalence of a MYC signaling signature in tumors of AfricanAmerican patients that was associated with the accumulation of the oncometabolite, 2-hydroxyglutarate. Earlier studies described race/ethnicity differences in the expression of cell cycle regulatory proteins, including p53, which is encoded by the TP53 tumor suppressor gene. ${ }^{32}$ These findings were confirmed when it was shown that tumors from African-American patients were more likely to carry a TP53 mutation. ${ }^{28,33}$ The high prevalence of triple-negative tumors in women of African descent accounts for much of this race/ ethnicity difference in the TP53 mutation's frequency because TP53 mutations are most common in this disease subtype. ${ }^{33,34}$ Interestingly, the tumor TP53 status has been associated with socioeconomic deprivation. ${ }^{35,36}$ Thus, an environmental factor related to socioeconomic status may promote the development of TP53 mutations in breast tumors. Alternatively, socioeconomic deprivation may specifically increase the risk of triple-negative breast cancer.

\section{Disparities in Molecular Subtypes of Prostate and Breast Cancer}

\section{Disparities in Molecular Subtypes of Prostate Cancer}

Prostate cancer evolves as a multistage disease with an accumulation of genomic aberrations during disease progression. ${ }^{37}$ Recurrent genomic rearrangements at cancer-related loci define prostate cancer subtypes. ${ }^{38}$ TMPRSS2:ERG gene fusion events, which produce fusion transcripts and oncogenic overexpression of $E R G$, an oncogene that encodes a member 
of the E26 transformation-specific (ETS) family of transcription factors, are signature mutations of a subset of prostate tumors and have important biological implications. ${ }^{39}$ Tumors carrying these gene fusions fall into a distinct molecular subtype. Other subtypes are negative for ETS-fusion gene arrangements but may overexpress the SPINK1 oncogene, or carry a $S P O P$ mutation, and have a poor prognosis. ${ }^{38,40}$ Conversely, localized prostate cancer contains few recurrent mutations in oncogenes or tumor suppressor. ${ }^{41}$ Instead, local prostate cancer is characterized by ETS-fusion gene arrangements and allelic gains of the $M Y C$ (alias c-myc) gene and deletions of the PTEN, TP53, and NKX3-1 tumor suppressors, with additional common changes in DNA methylation that increase aggressiveness. ${ }^{42,43}$ In stark contrast, nearly half of the metastatic castration-resistant prostate cancers harbor mutations in the androgen receptor, TP53, and PTEN genes and additional mutations in BRCA1, $B R C A 2$, and $A T M$, among others. ${ }^{44}$ However, because most studies included only patients of European descent, the mutational landscape of prostate cancer may not have been fully captured.

Multiple reports have shown that prostate tumors from patients of either European, African, or Asian descent exhibit notable differences in acquired chromosomal aberrations. ${ }^{40,45-47}$ These studies examined the frequency of recurrent ERG gene fusions and PTEN loss in diverse patient populations. Although common in European and European-American patients (40\% to $50 \%$ frequency), TMPRSS2:ERG gene fusion events were found to be significantly less frequent in African-American patients (20\% to $30 \%$ ) and were rather uncommon in patients from Asia in these studies (approximately 10\%). ${ }^{48}$ A similar pattern was observed for PTEN loss, with rates being significantly lower in Asian and African-American patients. ${ }^{47,48}$ These findings indicate robust race/ethnic differences in disease cause and mutational events affecting these patients.

\section{Disparities in Molecular Subtypes of Breast Cancer}

Breast cancer is a heterogeneous disease that encompasses at least four major molecular subtypes. Large-scale gene expression studies showed that breast tumors can be classified into subtypes with distinct gene expression. ${ }^{34}$ Molecular signatures characterize two luminal subtypes (A and B), the HER2 signaling-enriched tumors, and basallike tumors. Among the subtypes, basal-like and HER2positive tumors that are ER negative tend to yield the most aggressive disease. Basal-like tumors overlap largely with a group of tumors referred to as triple negative, which are negative for ER, HER2, and progesterone receptor expression. Research into novel therapies of breast cancer has focused on triple-negative tumors because these tumors are not treatable by current endocrine therapies, such as tamoxifen and aromatase inhibitors, or by HER2-targeting therapies, such as trastuzumab (Herceptin; Genentech/ Roche, South San Francisco, CA). It was recognized starting in 2006 that the prevalence of these subtypes varies among women in the United States, with the greatest difference observed between women of African and European descent. ${ }^{33,49}$ Investigations in West and Central Africa have provided further corroboration that women of African descent tend to develop early-onset, high-grade, ERnegative tumors more frequently than women of European descent. ${ }^{8}$ Early-onset ER-negative tumors also develop more frequently in women from India and Pakistan. ${ }^{50}$ Finally, cancer epidemiology showed that the rates of ERnegative breast tumors can change in a population over time, pointing to an influence of environmental and reproductive factors in the development of these tumors. ${ }^{51}$

\section{Immune-Inflammation Signatures in Breast and Prostate Tumors of African-American Patients}

\section{Immune-Inflammation Signatures in Prostate Cancer}

Inflammation and neoangiogenesis are key biological processes in cancer biology. ${ }^{52}$ Inflammation is also a putative risk factor for prostate cancer and has been associated with aggressive disease. ${ }^{53,54} \mathrm{We}$ and others have previously described a distinct immune-inflammation signature in prostate tumors of African-American patients, ${ }^{55-58}$ which is absent in most European-American patients (Table 1). Moreover, race/ethnicity differences in prostatic inflammation have been described in benign prostate tissues ${ }^{59,60}$ (Table 1), but their relationship to disease risk and aggressiveness remains unclear, because the findings in these two studies were not consistent. Because of the observations that tumors of African-American men commonly contain an immune-inflammation signature, we investigated the link between the regular use of aspirin, a nonsteroidal antiinflammatory drug, and prostate cancer. Regular aspirin use significantly reduces the risk of both advanced prostate cancer and disease recurrence in African-American men. ${ }^{61}$ Our observation that regular aspirin use increases diseasefree survival among these men confirms a similar observation in a previous study. ${ }^{62}$

Currently, no study has assessed whether men of African descent are affected by a systemic inflammatory process that increases the risk of lethal prostate cancer. However, there is evidence from the measurement of blood C-reactive protein levels that African Americans tend to have higher levels of this inflammation marker than European-Americans, ${ }^{61,63}$ indicating increased systemic inflammation. Although environmental exposures, including infections, promote systemic inflammation, ancestral factors may also influence inflammatory processes. For example, allele frequencies of genetic variants in inflammation-related genes can markedly differ among population groups. ${ }^{64}$ Therefore, ancestral factors may be a cause of the immune-inflammation signature in African-American prostate cancer patients. 
Table 1 Reports of Race/Ethnic Differences in Tumor-Associated Markers of Inflammation in Prostate Tumors

\begin{tabular}{ll}
\hline Tumor marker & Observation \\
\hline $\begin{array}{l}\text { Immune-inflammation } \\
\text { signatures }\end{array}$ & Rene expression differences between tumors from AA and EA men related to \\
immune response and inflammation. Prominent immune-inflammation signature & and a distinct interferon-related gene signature in AA tumors. \\
Increased expression of cytokines in AA tumors. & Distinct DNA copy number alterations in AA tumors. Alterations at the gene \\
& expression and DNA copy number levels point to differences in immune response \\
between AA and EA men. & \\
Increased expression of genes associated with immune response and inflammation \\
in AA tumors. A prominent interferon signature is present. \\
Pathology-based scoring of inflammation in benign prostate tissue from AA and EA \\
men. Inflammation was more prevalent in AA men. \\
Pathology-based scoring of acute and chronic inflammation in benign prostate \\
tissue from Asian, AA, EA, and Hispanic men, all participants of the REDUCE trial. \\
No race/ethnic differences in chronic inflammation but more acute inflammation \\
in Asian men, less in AA men, when compared with EA men. Acute inflammation \\
was associated with a lower prostate cancer risk.
\end{tabular}

AA, African-American; EA, European-American; REDUCE, A Clinical Research Study to Reduce the Incidence of Prostate Cancer in Men Who Are at Increased Risk.

In summary, there is evidence that prostate cancer patients of African descent experience an increased occurrence of a lowgrade chronic inflammation in their tumors. These observations suggest that disease progression and recurrence can be prevented, at least to some extent, with regular use of antiinflammatory drugs, such as aspirin, in this high-risk group of patients.

\section{Immune-Inflammation Signatures in Breast Cancer}

In breast cancer, an immune-inflammation signature describes a subset of triple-negative breast tumors. ${ }^{65}$ Inflammation in tumors includes the recruitment of tumor-associated macrophages (TAMs). Notably, their numbers were found to be elevated in breast tumors of African and African-American women by several investigators $^{28,66-68}$ (Table 2), suggesting an opportunity of targeting this immune environment as a therapeutic intervention. Moreover, Martin et $\mathrm{al}^{28}$ observed an increased microvessel density in these tumors. An elevated tumor vascularization in African-American breast cancer patients was also reported by Lindner et al. ${ }^{69}$ Tumor angiogenesis correlates with breast cancer metastasis and poor survival. ${ }^{70}$ Several mediators of inflammation contribute to increased angiogenesis and breast cancer progression. ${ }^{71}$ Aberrant expression of inflammation mediators, such as cyclooxygenase- 2 and inducible nitric oxide synthase, occurs in breast tumors. ${ }^{72,73}$ The significance of TAMs and an altered tumor microenvironment in the promotion of breast cancer progression is well documented. ${ }^{52,71}$ Thus, chronic inflammatory stimuli may have a crucial role in disease progression through inflammation-induced angiogenesis and tissue remodeling. Although solid evidence is still missing, current data suggest that inflammation-induced breast cancer progression may be more prevalent in patients of African descent and may relate to increased inflammatory cytokine levels in these women. ${ }^{74}$

\section{Differences in Cancer Epigenetics among Population Groups}

DNA methylation regulates gene expression and cell differentiation and is partly inherited. ${ }^{75}$ Environmental exposures and obesity can modify DNA methylation patterns and alter the tumor epigenome, as shown for prostate and breast cancer. ${ }^{76-78}$ Changes to DNA methylation are present in all cancers and cooperate with acquired genetic alterations to promote the cancer phenotype. ${ }^{79}$ Alterations in DNA methylation are among the earliest somatic changes that can be detected in cancerous lesions and occur at the stage of proliferative inflammatory atrophy, a precursor lesion in prostate cancer development. ${ }^{80}$ An aberrant increase in DNA methylation can lead to numerous downstream effects, including inactivation of PTEN, a bona fide tumor suppressor gene in prostate cancer, or a loss of GSTP1 expression, which is observed in $90 \%$ of prostate cancers. Epigenome-wide DNA methylation patterns have been linked to aggressive and lethal prostate cancer ${ }^{42,43}$ and to breast cancer recurrence, metastasis, and survival. ${ }^{81,82}$ Others have described molecular subgroups in breast cancer based on a global DNA methylation pattern. ${ }^{83}$ Hence, therapies that target the cancer epigenome are being developed. ${ }^{79}$

Race/ethnicity-related differences in DNA methylation have been observed in peripheral blood mononuclear cells of newborns. ${ }^{84}$ This study observed significant differences in DNA methylation affecting cancer-related loci, indicating that early life exposures may induce a DNA methylation 
Table 2 Reports of Race/Ethnic Differences in Immune Cell Numbers in Breast Tumors

\begin{tabular}{ll}
\hline Cancer type & Observation \\
\hline $\begin{array}{l}\text { Tumor-associated } \\
\text { macrophages }\end{array}$ & Rumber of CD68-positive macrophages is higher in breast tumors of AA patients \\
Proliferating cellular nuclear antigen-positive macrophages are increased in \\
breast tumors of Latina and AA women when compared with EA women. \\
High numbers of tumor-associated macrophages in breast tumors of Nigerian \\
women. \\
High immune cell infiltration, including CD163-positive macrophages, in breast \\
tumors of Kenyan women.
\end{tabular}

$A A$, African-American; EA, European-American.

pattern that later associates with disease susceptibility. Others reported a relationship between African ancestry and global DNA hypomethylation in blood leukocytes of cancer patients. ${ }^{85}$ Therefore, ancestry-related factors may influence the regulation of DNA methylation. Given the importance of epigenetic alterations in the development and progression of cancer, multiple investigators examined and compared DNA methylation in prostate and breast tumors of AfricanAmerican, European-American, and Asian patients using targeted and genome-wide approaches.

\section{Race/Ethnic Differences in Prostate Cancer Epigenetics}

In the prostate cancer studies, a pattern emerged consistent with an increased prevalence of DNA hypermethylation at several disease-related loci in African-American tumors when compared with similar stage tumors from EuropeanAmerican men ${ }^{86,87}$ (Table 3). Some of these alterations may relate to disease progression. Recently, the transcriptional regulator, KAISO, was found to be overexpressed in prostate tumors from African-American patients. ${ }^{25}$ KAISO recognizes clusters of methylated $\mathrm{CpG}$ nucleotides and enhances invasion of prostate cancer cells. This suggests that aberrant KAISO expression in tumors from AfricanAmerican men may enhance disease aggressiveness by mechanisms that include aberrant DNA methylation of cancer-related genomic loci.

\section{Race/Ethnic Differences in Breast Cancer Epigenetics}

In breast cancer studies, investigations focused on the differences in DNA methylation between African-American and European-American patients by analyzing tumors with both candidate gene and genome-wide approaches ${ }^{31,88-90}$ (Table 3). Differences in methylation between the two patient groups were reported for the ER-negative disease, but less so for the ER-positive disease. In general, the observed differences were not widespread but rather restricted to a few loci, and may be partially related to differences in MYC signaling among these patients. ${ }^{31}$ There is also evidence that some of the reported DNA methylation differences may not be tumor specific because similar patterns have been found in normal breast tissues and peripheral blood monocytes. ${ }^{89}$
To date, the mechanisms that lead to race/ethnicity differences in DNA methylation patterns of tumors are not fully understood. Whether these patterns are induced by ancestral genetic factors, the mutational landscape, environmental exposures, intrinsic differences in tumor biology, including cancer metabolism and metabolism-induced epigenetic alterations, or a combination of these factors also remains unknown. However, population differences in genome-wide DNA methylation have been described by Heyn et al. ${ }^{91}$ The study showed that two-thirds of the population-specific $\mathrm{CpG}$ sites were directly associated with the underlying genetic background of the populations. This finding indicates that inheritance and genetic ancestry are key drivers of epigenetic differences between populations that not only contribute to physical appearance, but may also contribute to traits, such as behavior, disease susceptibility, and disease aggressiveness.

\section{Stress Signaling-Mediated Effects in Cancer Biology and Disease Progression}

\section{Stress Signaling-Mediated Effects in Prostate Cancer}

Cancer epidemiology has linked stressful life events and discrimination to poor disease survival. ${ }^{92}$ Several investigations into the effects of stress exposures on tumor biology have also focused on prostate cancer. It was discovered that catecholamine signaling increases the metastatic phenotype of prostate cancer cells. ${ }^{93}$ Recently, a stressrelated signaling signature was found to occur in human prostate tumors, ${ }^{94}$ suggesting that environmentally induced stress signaling may adversely affect prostate cancer patients. Although there is no direct evidence that stress exposures affect prostate cancer patients from minority or disadvantaged backgrounds more so than other patients, a functional annotation of copy number and gene expression differences comparing tumors from African-American and EuropeanAmerican patients showed that these differences not only relate to immune function but also to neurotransmitter transport and catecholamine metabolic processes. ${ }^{57}$ Although the significance of these findings is unclear, the data suggest that differences in stress-induced catecholamine signaling may exist between the two patient groups. 
Table 3 Reports of Race/Ethnic Differences in Tumor DNA Methylation Patterns

\begin{tabular}{ll}
\hline Cancer type & Observation \\
\hline Prostate cancer & CpG hypermethylation of the GSTP1 promoter is more prevalent in prostate tumors of AA \\
men than EA or Asian men. \\
Globally higher DNA methylation in AA prostate tumors when compared with EA tumors in \\
a genome-wide DNA methylation analysis. \\
Prevalence of DNA methylation-defined tumor subtypes is different between AA and EA \\
patients. Using a genome-wide DNA methylation analysis, the authors identified a poor \\
survival tumor subtype with distinct DNA methylation, high tissue 2-hydroxyglutarate \\
levels, and heightened occurrence in AA patients. \\
Greater DNA methylation differences in ER-negative than ER-positive breast cancer, \\
comparing AA with EA women in a genome-wide DNA methylation analysis. Globally, \\
the number of differentially methylated CpG sites was low. \\
Few differences in promoter methylation between AA and EA breast cancer patients in the \\
tumors and in peripheral blood monocytes of these patients. More methylation \\
differences in ER-negative tumors. \\
In ER-negative breast cancer, AA patients had higher DNA methylation in four gene \\
promoters of a five-gene panel when compared with EA patients. Differences were only \\
observed among women with early-onset disease. No racial differences in ER-positive \\
breast cancer.
\end{tabular}

$A A$, African-American; EA, European-American; ER, estrogen receptor.

\section{Stress Signaling-Mediated Effects in Breast Cancer}

Stressful life events and perceived experiences of racism have a significant association with adverse health behaviors and breast cancer, ${ }^{95,96}$ whereas stress because of a cancer diagnosis may disproportionally affect minority populations. ${ }^{97}$ Social class, social isolation, and related stress affect immune cell function and tumor biology. In mice, chronic restraint stress decreased levels and function of p53 and promoted tumorigenesis. ${ }^{98}$ In women, Baker et al, ${ }^{35}$ and Starks et $\mathrm{al}^{36}$ observed a relationship between socioeconomic deprivation and an increased frequency of TP53 mutations in breast tumors. Other studies reported that social adversity in early life leads to resistance in glucocorticoid signaling and increased proinflammatory signaling. ${ }^{99}$ Social stress also affects the response to infections, telomere length, and immune cell function, and elevates the tumor catecholamine content. ${ }^{100,101}$ Thus, stress exposures have a potentially oncogenic function in tumor biology and may have a disproportionally high adverse impact in socially deprived and minority populations. Specifically, in breast cancer biology, social isolation can lead to reprogramming of tumor biology. ${ }^{102,103}$

Chronic stress influences tumor biology through two major pathways involving catecholamines and glucocorticoids. ${ }^{104}$ Stress-induced $\beta$-adrenergic signaling has been shown to promote cancer progression and metastasis in animal models of breast cancer. ${ }^{105,106}$ The mechanism by which this pathway promotes metastasis has been described and includes recruitment of TAMs and interactions between TAMs and cancer cells that cause increased tumor angiogenesis and distant metastasis. ${ }^{105,106}$ Recently, social isolation was found to be associated with elevated tumor catecholamine levels in human ovarian tumors and with a tumor gene signature, albeit this study was rather small. ${ }^{107}$ In 2010, it was first reported that $\beta$-blocker use after a disease diagnosis reduces disease recurrence and improves cancer-specific survival of breast cancer patients. ${ }^{108}$ In another study, users of the $\beta$-blocker, propranolol, were found to be significantly less likely to develop advanced breast cancer and have reduced breast cancer-specific mortality. ${ }^{109} \beta$-blocker use has also been associated with improved recurrence-free survival in triple-negative breast cancer. ${ }^{110}$ Jointly, these data indicate that stress may influence human breast cancer biology through activation of the prometastatic catecholamine pathway, leading to a poor outcome phenotype in a subpopulation of patients who would benefit from $\beta$-blocker use and stress management.

Our group observed that breast tumors from AfricanAmerican patients contained a higher microvessel density and more TAMs than tumors from European-American patients, independent of disease stage and tumor ER status. ${ }^{28}$ Because the phenotype is consistent with characteristics that are induced by catecholamine signaling in experimental models, ${ }^{105}$ our findings may indicate that increased signaling by this pathway occurs in tumors of these patients. Thus, inhibitors of catecholamine signaling may improve outcomes specifically among AfricanAmerican patients, which has not been examined thus far.

\section{Contribution of Population Genetics and Ancestry to Health Disparities}

Genetic ancestral factors not only characterize population groups but also participate in selection and can define phenotypic traits within populations. ${ }^{111}$ Several studies have shown that gene expression differences exist among 
populations that are attributable to common genetic variations and ancestral background. Two of these studies investigated gene expression variations between individuals of European and African ancestry (Nigeria) using lymphoblastoid cell lines. ${ }^{112,113}$ The researchers observed that these variations can cluster in disease-related pathways, raising the possibility that differences in common genetic variations among population groups cause population-specific susceptibilities for common diseases, like cancer, because of their effect on the transcriptome.

\section{Contribution of Ancestry to Prostate Cancer Health Disparities}

Prostate cancer is a genetically heterogeneous disease, in which inherited factors may account for approximately $40 \%$ to $50 \%$ of the cases. ${ }^{114}$ Several familial susceptibility genes have been described, including RNASEL, BRCA1, BRCA2, and HOXB13. Germline mutations in these genes account for $5 \%$ to $10 \%$ of all prostate cancer cases. Most of the inherited risk for prostate cancer arises from common genetic variants. Approximately 100 disease susceptibility loci are currently known, ${ }^{9}$ but not all of them confer risk in men of African ancestry. ${ }^{115}$ Numerous studies have examined the possibility of low-penetrance genes contributing to the excessive burden of prostate cancer in men of African ancestry. To date, the best characterized risk locus for prostate cancer is located at $8 \mathrm{q} 24$. This locus likely affects tumor biology because it encodes an enhancer region that regulates MYC in an allele-specific manner. ${ }^{116}$ Multiple common variants within this locus increase the risk of prostate cancer in diverse populations. ${ }^{117-119}$ As shown by admixture mapping and genome-wide association studies, 8q24 confers an even higher risk for prostate cancer in men of West African ancestry, when compared with men of European and Asian ancestry, partly explained by variants that were only found in men of African ancestry. ${ }^{117,118,120}$ Thus, the 8q24 region accounts for at least some of the excessive disease risk among men of African ancestry. A susceptibility locus at $17 \mathrm{q} 21$ has been identified as another genetic risk factor that appears to be restricted to men of African ancestry. ${ }^{121}$ However, few common genetic variations have been associated with prostate cancer aggressiveness, mortality, or response to therapy, ${ }^{122}$ and none has been associated with increased mortality among men of African ancestry.

\section{Contribution of Ancestry to Breast Cancer Health Disparities}

Genome-wide association studies and admixture mapping have also been used to examine the contribution of inherited risk to breast cancer and to the excessive risk of breast cancer mortality among women of African and Latina descent. Numerous genome-wide association studies showed that a large set of common genetic variants defines the risk of breast cancer, the ER- and triple-negative disease, and breast cancer survival. ${ }^{123-126}$ The most strongly associated risk locus has been mapped to the region containing fibroblast growth factor receptor $2 .{ }^{123}$ However, an analysis within the Multiethnic Cohort Study observed significant population heterogeneity for the association of 12 highly replicated single-nucleotide polymorphisms with breast cancer and did not find an association of these singlenucleotide polymorphisms with breast cancer in African Americans. ${ }^{127}$ Additional studies did not replicate genomewide association study findings from European populations in populations of African ancestry. ${ }^{128}$ Instead, different lowpenetrance risk loci for breast cancer may exist in populations of African ancestry. ${ }^{129-131}$ One study suggested that a common variant at the TERT-CLPTMIL locus may be an underlying cause for the high prevalence of ER-negative tumors among women of African ancestry. ${ }^{132}$ Admixture scans in African-American and Latina women with breast cancer further support the concept of ancestry-related risk factors in breast cancer. Two studies of Latina women found that European and indigenous American ancestry are significantly associated with breast cancer risk and survival, respectively, in this population. ${ }^{133}$ Admixture mapping of African-American women identified new breast cancer risk loci for this population. ${ }^{134}$

Together, these data show that population genetics and ancestry likely contribute to existing health disparities and partly explain the increased risk of prostate cancer among men of African ancestry, whereas these factors may also promote an excessive breast cancer mortality among African-American and Latina women.

\section{Conclusions}

Not all segments of the US population have equally benefited from the advances in our knowledge and treatment of cancer. Minority, immigrant, and disadvantaged populations continue to experience an excessive cancer burden. This burden is not only attributable to barriers in access to health care and cultural obstacles, but is also attributable to distinct carcinogen and pathogen exposures, environmentally induced stress, comorbidities, and ancestry-related risk factors. These factors, singularly or in combination, are the likely causes of the existing cancer health disparities in the United States and globally. There is strong evidence from migration studies that the environment defines cancer risk, but there is also evidence that population differences in genetic ancestry can lead to population differences in cancer susceptibility. One mechanism by which environmental and ancestry-related factors affect health outcomes is by inducing an adverse tumor biology. Multiple studies have identified differences in tumor biology and epigenetic factors among diverse patient populations. For example, the analysis of tumor markers revealed the existence of tumor biological and mutational differences in prostate cancer among patients of African, European, and Asian descent. These differences indicate disparities in disease cause and 
may arise from pathogenic mechanisms that are different between population groups. Environmental factors have also been shown to define the cause of many cancer types, and both environmentally induced stress and toxins from tobacco smoke can induce a tumor biology that increases the odds of a metastatic disease. ${ }^{105,135}$ Changes in tumor biology attributable to modifiable risk factors may also affect early disease detection and the response to therapy. These changes may contribute to a distinct disease presentation of prostate cancer among men of African descent, including the excessive mortality in this patient group in the United States and globally. Thus, gaining an understanding of tumor biology in diverse patient populations can advance cancer health disparity research and provide new insights that can be harnessed to improve cancer prevention and care and to reduce or eliminate outcome disparities in cancer.

\section{References}

1. Byers T: Two decades of declining cancer mortality: progress with disparity. Annu Rev Public Health 2010, 31:121-132

2. Siegel RL, Miller KD, Jemal A: Cancer statistics, 2016. CA Cancer J Clin 2016, 66:7-30

3. Siegel R, Ward E, Brawley O, Jemal A: Cancer statistics, 2011: the impact of eliminating socioeconomic and racial disparities on premature cancer deaths. CA Cancer J Clin 2011, 61:212-236

4. DeSantis CE, Siegel RL, Sauer AG, Miller KD, Fedewa SA, Alcaraz KI, Jemal A: Cancer statistics for African Americans, 2016 : progress and opportunities in reducing racial disparities. CA Cancer J Clin 2016, 66:290-308

5. O'Keefe EB, Meltzer JP, Bethea TN: Health disparities and cancer: racial disparities in cancer mortality in the United States, 2000-2010. Front Public Health 2015, 3:51

6. Desantis C, Siegel R, Bandi P, Jemal A: Breast cancer statistics, 2011. CA Cancer J Clin 2011, 61:409-418

7. Zeigler-Johnson CM, Rennert H, Mittal RD, Jalloh M, Sachdeva R, Malkowicz SB, Mandhani A, Mittal B, Gueye SM, Rebbeck TR: Evaluation of prostate cancer characteristics in four populations worldwide. Can J Urol 2008, 15:4056-4064

8. Huo D, Ikpatt F, Khramtsov A, Dangou JM, Nanda R, Dignam J, Zhang B, Grushko T, Zhang C, Oluwasola O, Malaka D, Malami S, Odetunde A, Adeoye AO, Iyare F, Falusi A, Perou CM, Olopade OI: Population differences in breast cancer: survey in indigenous African women reveals over-representation of triple-negative breast cancer. J Clin Oncol 2009, 27:4515-4521

9. Al Olama AA, Kote-Jarai Z, Berndt SI, Conti DV, Schumacher F, Han Y, et al: A meta-analysis of 87,040 individuals identifies 23 new susceptibility loci for prostate cancer. Nat Genet 2014, 46: 1103-1109

10. Pietro GD, Chornokur G, Kumar NB, Davis C, Park JY: Racial differences in the diagnosis and treatment of prostate cancer. Int Neurourol J 2016, 20:S112-S119

11. Mariotto AB, Etzioni R, Krapcho M, Feuer EJ: Reconstructing PSA testing patterns between black and white men in the US from Medicare claims and the National Health Interview Survey. Cancer 2007, 109:1877-1886

12. Aizer AA, Wilhite TJ, Chen MH, Graham PL, Choueiri TK, Hoffman KE, Martin NE, Trinh QD, Hu JC, Nguyen PL: Lack of reduction in racial disparities in cancer-specific mortality over a 20 year period. Cancer 2014, 120:1532-1539

13. Odedina FT, Akinremi TO, Chinegwundoh F, Roberts R, Yu D, Reams RR, Freedman ML, Rivers B, Green BL, Kumar N: Prostate cancer disparities in black men of African descent: a comparative literature review of prostate cancer burden among black men in the United States, Caribbean, United Kingdom, and West Africa. Infect Agent Cancer 2009, 4 Suppl 1:S2

14. Tyson MD 2nd, Castle EP: Racial disparities in survival for patients with clinically localized prostate cancer adjusted for treatment effects. Mayo Clin Proc 2014, 89:300-307

15. Powell IJ, Bock CH, Ruterbusch JJ, Sakr W: Evidence supports a faster growth rate and/or earlier transformation to clinically significant prostate cancer in black than in white American men, and influences racial progression and mortality disparity. J Urol 2010, 183: 1792-1796

16. Silber JH, Rosenbaum PR, Clark AS, Giantonio BJ, Ross RN, Teng Y, Wang M, Niknam BA, Ludwig JM, Wang W, EvenShoshan O, Fox KR: Characteristics associated with differences in survival among black and white women with breast cancer. JAMA 2013, 310:389-397

17. Jatoi I, Becher $\mathrm{H}$, Leake CR: Widening disparity in survival between white and African-American patients with breast carcinoma treated in the U. S. Department of Defense Healthcare system. Cancer 2003, 98 : 894-899

18. Albain KS, Unger JM, Crowley JJ, Coltman CA Jr, Hershman DL: Racial disparities in cancer survival among randomized clinical trials patients of the Southwest Oncology Group. J Natl Cancer Inst 2009, 101:984-992

19. Menashe I, Anderson WF, Jatoi I, Rosenberg PS: Underlying causes of the black-white racial disparity in breast cancer mortality: a population-based analysis. J Natl Cancer Inst 2009, 101:993-1000

20. Hershman D, McBride R, Jacobson JS, Lamerato L, Roberts K, Grann VR, Neugut AI: Racial disparities in treatment and survival among women with early-stage breast cancer. J Clin Oncol 2005, 23 : 6639-6646

21. Thomas DB, Karagas MR: Cancer in first and second generation Americans. Cancer Res 1987, 47:5771-5776

22. Maskarinec G, Noh JJ: The effect of migration on cancer incidence among Japanese in Hawaii. Ethn Dis 2004, 14:431-439

23. Shuch B, Mikhail M, Satagopan J, Lee P, Yee H, Chang C, CordonCardo C, Taneja SS, Osman I: Racial disparity of epidermal growth factor receptor expression in prostate cancer. J Clin Oncol 2004, 22 : 4673-4677

24. Petrovics G, Zhang W, Makarem M, Street JP, Connelly R, Sun L, Sesterhenn IA, Srikantan V, Moul JW, Srivastava S: Elevated expression of PCGEM1, a prostate-specific gene with cell growthpromoting function, is associated with high-risk prostate cancer patients. Oncogene 2004, 23:605-611

25. Jones J, Wang H, Zhou J, Hardy S, Turner T, Austin D, He Q, Wells A, Grizzle WE, Yates C: Nuclear kaiso indicates aggressive prostate cancers and promotes migration and invasiveness of prostate cancer cells. Am J Pathol 2012, 181:1836-1846

26. Zhang L, Wang J, Wang Y, Zhang Y, Castro P, Shao L, Sreekumar A, Putluri N, Guha N, Deepak S, Padmanaban A, Creighton CJ, Ittmann M: MNX1 is oncogenically upregulated in African-American prostate cancer. Cancer Res 2016, 76:6290-6298

27. Petrovics G, Li H, Stumpel T, Tan SH, Young D, Katta S, Li Q, Ying K, Klocke B, Ravindranath L, Kohaar I, Chen Y, Ribli D, Grote K, Zou H, Cheng J, Dalgard CL, Zhang S, Csabai I, Kagan J, Takeda D, Loda M, Srivastava S, Scherf M, Seifert M, Gaiser T, McLeod DG, Szallasi Z, Ebner R, Werner T, Sesterhenn IA, Freedman M, Dobi A, Srivastava S: A novel genomic alteration of LSAMP associates with aggressive prostate cancer in African American men. EBioMedicine 2015, 2:1957-1964

28. Martin DN, Boersma BJ, Yi M, Reimers M, Howe TM, Yfantis HG, Tsai YC, Williams EH, Lee DH, Stephens RM, Weissman AM, Ambs S: Differences in the tumor microenvironment between African-American and European-American breast cancer patients. PLoS One 2009, 4:e4531

29. Field LA, Love B, Deyarmin B, Hooke JA, Shriver CD, Ellsworth RE: Identification of differentially expressed genes in 
breast tumors from African American compared with Caucasian women. Cancer 2012, 118:1334-1344

30. D'Arcy M, Fleming J, Robinson WR, Kirk EL, Perou CM, Troester MA: Race-associated biological differences among luminal A breast tumors. Breast Cancer Res Treat 2015, 152:437-448

31. Terunuma A, Putluri N, Mishra P, Mathe EA, Dorsey TH, Yi M, Wallace TA, Issaq HJ, Zhou M, Killian JK, Stevenson HS, Karoly ED, Chan K, Samanta S, Prieto D, Hsu TY, Kurley SJ, Putluri V, Sonavane R, Edelman DC, Wulff J, Starks AM, Yang Y, Kittles RA, Yfantis HG, Lee DH, Ioffe OB, Schiff R, Stephens RM, Meltzer PS, Veenstra TD, Westbrook TF, Sreekumar A, Ambs S: MYC-driven accumulation of 2-hydroxyglutarate is associated with breast cancer prognosis. J Clin Invest 2014, 124:398-412

32. Jones BA, Kasl SV, Howe CL, Lachman M, Dubrow R, Curnen MM, Soler-Vila H, Beeghly A, Duan F, Owens P: African-American/white differences in breast carcinoma: p53 alterations and other tumor characteristics. Cancer 2004, 101:1293-1301

33. Keenan T, Moy B, Mroz EA, Ross K, Niemierko A, Rocco JW, Isakoff S, Ellisen LW, Bardia A: Comparison of the genomic landscape between primary breast cancer in African American versus white women and the association of racial differences with tumor recurrence. J Clin Oncol 2015, 33:3621-3627

34. Cancer Genome Atlas Network: Comprehensive molecular portraits of human breast tumours. Nature 2012, 490:61-70

35. Baker L, Quinlan PR, Patten N, Ashfield A, Birse-Stewart-Bell LJ, McCowan C, Bourdon JC, Purdie CA, Jordan LB, Dewar JA, Wu L, Thompson AM: p53 Mutation, deprivation and poor prognosis in primary breast cancer. Br J Cancer 2010, 102:719-726

36. Starks AM, Martin DN, Dorsey TH, Boersma BJ, Wallace TA, Ambs S: Household income is associated with the p53 mutation frequency in human breast tumors. PLoS One 2013, 8:e57361

37. Abate-Shen C, Shen MM: Molecular genetics of prostate cancer. Genes Dev 2000, 14:2410-2434

38. Attard G, Parker C, Eeles RA, Schroder F, Tomlins SA, Tannock I, Drake CG, de Bono JS: Prostate cancer. Lancet 2016, 387:70-82

39. Rosen P, Sesterhenn IA, Brassell SA, McLeod DG, Srivastava S, Dobi A: Clinical potential of the ERG oncoprotein in prostate cancer. Nat Rev Urol 2012, 9:131-137

40. Faisal FA, Sundi D, Tosoian JJ, Choeurng V, Alshalalfa M, Ross AE, Klein E, Den R, Dicker A, Erho N, Davicioni E, Lotan TL, Schaeffer EM: Racial variations in prostate cancer molecular subtypes and androgen receptor signaling reflect anatomic tumor location. Eur Urol 2016, 70:14-17

41. Fraser M, Sabelnykova VY, Yamaguchi TN, Heisler LE, Livingstone J, Huang V, et al: Genomic hallmarks of localized, nonindolent prostate cancer. Nature 2017, 541:359-364

42. Zhao S, Geybels MS, Leonardson A, Rubicz R, Kolb S, Yan Q, Klotzle B, Bibikova M, Hurtado-Coll A, Troyer D, Lance R, Lin DW, Wright JL, Ostrander EA, Fan JB, Feng Z, Stanford JL: Epigenomewide tumor DNA methylation profiling identifies novel prognostic biomarkers of metastatic-lethal progression in men diagnosed with clinically localized prostate cancer. Clin Cancer Res 2017, 23: $311-319$

43. Mundbjerg K, Chopra S, Alemozaffar M, Duymich C, Lakshminarasimhan R, Nichols PW, Aron M, Siegmund KD, Ukimura O, Aron M, Stern M, Gill P, Carpten JD, Orntoft TF, Sorensen KD, Weisenberger DJ, Jones PA, Duddalwar V, Gill I, Liang G: Identifying aggressive prostate cancer foci using a DNA methylation classifier. Genome Biol 2017, 18:3

44. Robinson D, Van Allen EM, Wu YM, Schultz N, Lonigro RJ, Mosquera JM, et al: Integrative clinical genomics of advanced prostate cancer. Cell 2015, 161:1215-1228

45. Magi-Galluzzi C, Tsusuki T, Elson P, Simmerman K, Lafargue C, Esgueva R, Klein E, Rubin MA, Zhou M: TMPRSS2-ERG gene fusion prevalence and class are significantly different in prostate cancer of Caucasian, African-American and Japanese patients. Prostate $2011,71: 489-497$
46. Khani F, Mosquera JM, Park K, Blattner M, O'Reilly C, MacDonald TY, Chen Z, Srivastava A, Tewari AK, Barbieri CE, Rubin MA, Robinson BD: Evidence for molecular differences in prostate cancer between African American and Caucasian men. Clin Cancer Res 2014, 20:4925-4934

47. Tosoian JJ, Almutairi F, Morais CL, Glavaris S, Hicks J, Sundi D, Humphreys E, Han M, De Marzo AM, Ross AE, Tomlins SA, Schaeffer EM, Trock BJ, Lotan TL: Prevalence and prognostic significance of PTEN loss in African-American and European-American men undergoing radical prostatectomy. Eur Urol 2017, 71:697-700

48. Martin DN, Starks AM, Ambs S: Biological determinants of health disparities in prostate cancer. Curr Opin Oncol 2013, 25:235-241

49. Carey LA, Perou CM, Livasy CA, Dressler LG, Cowan D, Conway K, Karaca G, Troester MA, Tse CK, Edmiston S, Deming SL, Geradts J, Cheang MC, Nielsen TO, Moorman PG, Earp HS, Millikan RC: Race, breast cancer subtypes, and survival in the Carolina Breast Cancer Study. JAMA 2006, 295:2492-2502

50. Kakarala M, Rozek L, Cote M, Liyanage S, Brenner DE: Breast cancer histology and receptor status characterization in Asian Indian and Pakistani women in the U.S.: a SEER analysis. BMC Cancer 2010, 10:191

51. Hausauer AK, Keegan TH, Chang ET, Clarke CA: Recent breast cancer trends among Asian/Pacific Islander, Hispanic, and AfricanAmerican women in the US: changes by tumor subtype. Breast Cancer Res 2007, 9:R90

52. Coussens LM, Werb Z: Inflammation and cancer. Nature 2002, 420: 860-867

53. Gurel B, Lucia MS, Thompson IM Jr, Goodman PJ, Tangen CM, Kristal AR, Parnes HL, Hoque A, Lippman SM, Sutcliffe S, Peskoe SB, Drake CG, Nelson WG, De Marzo AM, Platz EA: Chronic inflammation in benign prostate tissue is associated with high-grade prostate cancer in the placebo arm of the prostate cancer prevention trial. Cancer Epidemiol Biomarkers Prev 2014, 23: 847-856

54. Klink JC, Banez LL, Gerber L, Lark A, Vollmer RT, Freedland SJ: Intratumoral inflammation is associated with more aggressive prostate cancer. World J Urol 2013, 31:1497-1503

55. Wallace TA, Prueitt RL, Yi M, Howe TM, Gillespie JW, Yfantis HG, Stephens RM, Caporaso NE, Loffredo CA, Ambs S: Tumor immunobiological differences in prostate cancer between AfricanAmerican and European-American men. Cancer Res 2008, 68: 927-936

56. Powell IJ, Dyson G, Land S, Ruterbusch J, Bock CH, Lenk S, Herawi M, Everson R, Giroux CN, Schwartz AG, Bollig-Fischer A: Genes associated with prostate cancer are differentially expressed in African American and European American men. Cancer Epidemiol Biomarkers Prev 2013, 22:891-897

57. Rose AE, Satagopan JM, Oddoux C, Zhou Q, Xu R, Olshen AB, Yu JZ, Dash A, Jean-Gilles J, Reuter V, Gerald WL, Lee P, Osman I: Copy number and gene expression differences between African American and Caucasian American prostate cancer. J Transl Med 2010, $8: 70$

58. Hardiman G, Savage SJ, Hazard ES, Wilson RC, Courtney SM, Smith MT, Hollis BW, Halbert CH, Gattoni-Celli S: Systems analysis of the prostate transcriptome in African-American men compared with European-American men. Pharmacogenomics 2016, 17: $1129-1143$

59. Eastham JA, May RA, Whatley T, Crow A, Venable DD, Sartor O: Clinical characteristics and biopsy specimen features in AfricanAmerican and white men without prostate cancer. J Natl Cancer Inst 1998, 90:756-760

60. Vidal AC, Chen Z, Howard LE, Moreira DM, Castro-Santamaria R, Andriole GL, Taioli E, Fowke JH, Knudsen B, Drake CG, Nickel JC, Freedland SJ: Racial differences in prostate inflammation: results from the REDUCE study. Oncotarget 2016, 8:71393-71399

61. Smith CJ, Dorsey TH, Tang W, Jordan SV, Loffredo CA, Ambs S: Aspirin use reduces the risk of aggressive prostate cancer and disease 
recurrence in African-American men. Cancer Epidemiol Biomarkers Prev 2017, 26:845-853

62. Osborn VW, Chen SC, Weiner J, Schwartz D, Schreiber D: Impact of aspirin on clinical outcomes for African American men with prostate cancer undergoing radiation. Tumori 2016, 102:65-70

63. Khera A, McGuire DK, Murphy SA, Stanek HG, Das SR, Vongpatanasin W, Wians FH Jr, Grundy SM, de Lemos JA: Race and gender differences in C-reactive protein levels. J Am Coll Cardiol 2005, 46:464-469

64. Van Dyke AL, Cote ML, Wenzlaff AS, Land S, Schwartz AG: Cytokine SNPs: comparison of allele frequencies by race and implications for future studies. Cytokine 2009, 46:236-244

65. Lehmann BD, Bauer JA, Chen X, Sanders ME, Chakravarthy AB, Shyr Y, Pietenpol JA: Identification of human triple-negative breast cancer subtypes and preclinical models for selection of targeted therapies. J Clin Invest 2011, 121:2750-2767

66. Mukhtar RA, Moore AP, Nseyo O, Baehner FL, Au A, Moore DH, Twomey P, Campbell MJ, Esserman LJ: Elevated PCNA + tumorassociated macrophages in breast cancer are associated with early recurrence and non-Caucasian ethnicity. Breast Cancer Res Treat 2011, 130:635-644

67. Adisa CA, Eleweke N, Alfred AA, Campbell MJ, Sharma R, Nseyo O, Tandon V, Mukhtar R, Greninger A, Risi JD, Esserman LJ: Biology of breast cancer in Nigerian women: a pilot study. Ann Afr Med 2012, 11:169-175

68. Sawe RT, Kerper M, Badve S, Li J, Sandoval-Cooper M, Xie J, Shi Z, Patel K, Chumba D, Ofulla A, Prosperi J, Taylor K, Stack MS, Mining S, Littlepage LE: Aggressive breast cancer in western Kenya has early onset, high proliferation, and immune cell infiltration. BMC Cancer 2016, 16:204

69. Lindner R, Sullivan C, Offor O, Lezon-Geyda K, Halligan K, Fischbach N, Shah M, Bossuyt V, Schulz V, Tuck DP, Harris LN: Molecular phenotypes in triple negative breast cancer from African American patients suggest targets for therapy. PLoS One 2013, 8: e71915

70. Weidner $\mathrm{N}$ : Intratumor microvessel density as a prognostic factor in cancer. Am J Pathol 1995, 147:9-19

71. Lewis CE, Leek R, Harris A, McGee JO: Cytokine regulation of angiogenesis in breast cancer: the role of tumor-associated macrophages. J Leukoc Biol 1995, 57:747-751

72. Glynn SA, Prueitt RL, Ridnour LA, Boersma BJ, Dorsey TM, Wink DA, Goodman JE, Yfantis HG, Lee DH, Ambs S: COX-2 activation is associated with Akt phosphorylation and poor survival in ER-negative, HER2-positive breast cancer. BMC Cancer 2010 , 10:626

73. Glynn SA, Boersma BJ, Dorsey TH, Yi M, Yfantis HG, Ridnour LA, Martin DN, Switzer CH, Hudson RS, Wink DA, Lee DH, Stephens RM, Ambs S: Increased NOS2 predicts poor survival in estrogen receptor-negative breast cancer patients. J Clin Invest 2010 , 120:3843-3854

74. Park NJ, Kang DH: Inflammatory cytokine levels and breast cancer risk factors: racial differences of healthy Caucasian and African American women. Oncol Nurs Forum 2013, 40:490-500

75. Jones PA, Liang G: Rethinking how DNA methylation patterns are maintained. Nat Rev Genet 2009, 10:805-811

76. Enokida H, Shiina H, Urakami S, Terashima M, Ogishima T, Li LC, Kawahara M, Nakagawa M, Kane CJ, Carroll PR, Igawa M, Dahiya R: Smoking influences aberrant CpG hypermethylation of multiple genes in human prostate carcinoma. Cancer 2006, 106: 79-86

77. Christensen BC, Kelsey KT, Zheng S, Houseman EA, Marsit CJ, Wrensch MR, Wiemels JL, Nelson HH, Karagas MR, Kushi LH, Kwan ML, Wiencke JK: Breast cancer DNA methylation profiles are associated with tumor size and alcohol and folate intake. PLoS Genet 2010, 6:e1001043

78. Hair BY, Troester MA, Edmiston SN, Parrish EA, Robinson WR, Wu MC, Olshan AF, Swift-Scanlan T, Conway K: Body mass index is associated with gene methylation in estrogen receptor-positive breast tumors. Cancer Epidemiol Biomarkers Prev 2015, 24:580-586

79. Baylin SB, Jones PA: Epigenetic determinants of cancer. Cold Spring Harb Perspect Biol 2016, 8. a019505

80. Nelson WG, De Marzo AM, Yegnasubramanian S: Epigenetic alterations in human prostate cancers. Endocrinology 2009, 150: 3991-4002

81. Fackler MJ, Umbricht CB, Williams D, Argani P, Cruz LA, Merino VF, Teo WW, Zhang Z, Huang P, Visvananthan K, Marks J, Ethier S, Gray JW, Wolff AC, Cope LM, Sukumar S: Genome-wide methylation analysis identifies genes specific to breast cancer hormone receptor status and risk of recurrence. Cancer Res 2011, 71: 6195-6207

82. Fang F, Turcan S, Rimner A, Kaufman A, Giri D, Morris LG, Shen R, Seshan V, Mo Q, Heguy A, Baylin SB, Ahuja N, Viale A, Massague J, Norton L, Vahdat LT, Moynahan ME, Chan TA: Breast cancer methylomes establish an epigenomic foundation for metastasis. Sci Trans1 Med 2011, 3:75ra25

83. Dedeurwaerder S, Desmedt C, Calonne E, Singhal SK, HaibeKains B, Defrance M, Michiels S, Volkmar M, Deplus R, Luciani J, Lallemand F, Larsimont D, Toussaint J, Haussy S, Rothe F, Rouas G, Metzger O, Majjaj S, Saini K, Putmans P, Hames G, van Baren N, Coulie PG, Piccart M, Sotiriou C, Fuks F: DNA methylation profiling reveals a predominant immune component in breast cancers. EMBO Mol Med 2011, 3:726-741

84. Adkins RM, Krushkal J, Tylavsky FA, Thomas F: Racial differences in gene-specific DNA methylation levels are present at birth. Birth Defects Res A Clin Mol Teratol 2011, 91:728-736

85. Cappetta M, Berdasco M, Hochmann J, Bonilla C, Sans M, Hidalgo PC, Artagaveytia N, Kittles R, Martinez M, Esteller M, Bertoni B: Effect of genetic ancestry on leukocyte global DNA methylation in cancer patients. BMC Cancer 2015, 15:434

86. Enokida H, Shiina H, Urakami S, Igawa M, Ogishima T, Pookot D, Li LC, Tabatabai ZL, Kawahara M, Nakagawa M, Kane CJ, Carroll PR, Dahiya R: Ethnic group-related differences in $\mathrm{CpG}$ hypermethylation of the GSTP1 gene promoter among AfricanAmerican, Caucasian and Asian patients with prostate cancer. Int J Cancer 2005, 116:174-181

87. Devaney JM, Wang S, Furbert-Harris P, Apprey V, Ittmann M, Wang BD, Olender J, Lee NH, Kwabi-Addo B: Genome-wide differentially methylated genes in prostate cancer tissues from African-American and Caucasian men. Epigenetics 2015, 10: 319-328

88. Ambrosone CB, Young AC, Sucheston LE, Wang D, Yan L, Liu S, Tang L, Hu Q, Freudenheim JL, Shields PG, Morrison CD, Demissie K, Higgins MJ: Genome-wide methylation patterns provide insight into differences in breast tumor biology between American women of African and European ancestry. Oncotarget 2013, 5: $237-248$

89. Conway K, Edmiston SN, Tse CK, Bryant C, Kuan PF, Hair BY, Parrish EA, May R, Swift-Scanlan T: Racial variation in breast tumor promoter methylation in the Carolina Breast Cancer Study. Cancer Epidemiol Biomarkers Prev 2015, 24:921-930

90. Mehrotra J, Ganpat MM, Kanaan Y, Fackler MJ, McVeigh M, Lahti-Domenici J, Polyak K, Argani P, Naab T, Garrett E, Parmigiani G, Broome C, Sukumar S: Estrogen receptor/progesterone receptor-negative breast cancers of young African-American women have a higher frequency of methylation of multiple genes than those of Caucasian women. Clin Cancer Res 2004, 10: 2052-2057

91. Heyn H, Moran S, Hernando-Herraez I, Sayols S, Gomez A, Sandoval J, Monk D, Hata K, Marques-Bonet T, Wang L, Esteller M: DNA methylation contributes to natural human variation. Genome Res 2013, 23:1363-1372

92. Chida Y, Hamer M, Wardle J, Steptoe A: Do stress-related psychosocial factors contribute to cancer incidence and survival? Nat Clin Pract Oncol 2008, 5:466-475 
93. Palm D, Lang K, Niggemann B, Drell TL, Masur K, Zaenker KS, Entschladen F: The norepinephrine-driven metastasis development of PC-3 human prostate cancer cells in BALB/c nude mice is inhibited by beta-blockers. Int J Cancer 2006, 118:2744-2749

94. Lu D, Sinnott JA, Valdimarsdottir U, Fang F, Gerke T, Tyekucheva S, Fiorentino M, Lambe M, Sesso HD, Sweeney CJ, Wilson KM, Giovannucci EL, Loda M, Mucci LA, Fall K: Stressrelated signaling pathways in lethal and nonlethal prostate cancer. Clin Cancer Res 2016, 22:765-772

95. Taylor TR, Williams CD, Makambi KH, Mouton C, Harrell JP, Cozier Y, Palmer JR, Rosenberg L, Adams-Campbell LL: Racial discrimination and breast cancer incidence in US black women: the Black Women's Health Study. Am J Epidemiol 2007, 166:46-54

96. Shariff-Marco S, Klassen AC, Bowie JV: Racial/ethnic differences in self-reported racism and its association with cancer-related health behaviors. Am J Public Health 2010, 100:364-374

97. Vin-Raviv N, Hillyer GC, Hershman DL, Galea S, Leoce N, Bovbjerg DH, Kushi LH, Kroenke C, Lamerato L, Ambrosone CB, Valdimorsdottir H, Jandorf L, Mandelblatt JS, Tsai WY, Neugut AI: Racial disparities in posttraumatic stress after diagnosis of localized breast cancer: the BQUAL study. J Natl Cancer Inst 2013, 105:563-572

98. Feng Z, Liu L, Zhang C, Zheng T, Wang J, Lin M, Zhao Y, Wang X, Levine AJ, Hu W: Chronic restraint stress attenuates p53 function and promotes tumorigenesis. Proc Natl Acad Sci U S A 2012, 109: 7013-7018

99. Miller GE, Chen E, Fok AK, Walker H, Lim A, Nicholls EF, Cole S, Kobor MS: Low early-life social class leaves a biological residue manifested by decreased glucocorticoid and increased proinflammatory signaling. Proc Natl Acad Sci U S A 2009, 106: 14716-14721

100. Cole SW, Hawkley LC, Arevalo JM, Cacioppo JT: Transcript origin analysis identifies antigen-presenting cells as primary targets of socially regulated gene expression in leukocytes. Proc Natl Acad Sci U S A 2011, 108:3080-3085

101. Entringer S, Epel ES, Kumsta R, Lin J, Hellhammer DH, Blackburn EH, Wust S, Wadhwa PD: Stress exposure in intrauterine life is associated with shorter telomere length in young adulthood. Proc Natl Acad Sci U S A 2011, 108:E513-E518

102. Williams JB, Pang D, Delgado B, Kocherginsky M, Tretiakova M, Krausz T, Pan D, He J, McClintock MK, Conzen SD: A model of gene-environment interaction reveals altered mammary gland gene expression and increased tumor growth following social isolation. Cancer Prev Res (Phila) 2009, 2:850-861

103. Volden PA, Wonder EL, Skor MN, Carmean CM, Patel FN, Ye H, Kocherginsky M, McClintock MK, Brady MJ, Conzen SD: Chronic social isolation is associated with metabolic gene expression changes specific to mammary adipose tissue. Cancer Prev Res (Phila) 2013, 6: 634-645

104. Antoni MH, Lutgendorf SK, Cole SW, Dhabhar FS, Sephton SE, McDonald PG, Stefanek M, Sood AK: The influence of biobehavioural factors on tumour biology: pathways and mechanisms. Nat Rev Cancer 2006, 6:240-248

105. Sloan EK, Priceman SJ, Cox BF, Yu S, Pimentel MA, Tangkanangnukul V, Arevalo JM, Morizono K, Karanikolas BD, Wu L, Sood AK, Cole SW: The sympathetic nervous system induces a metastatic switch in primary breast cancer. Cancer Res 2010, 70: $7042-7052$

106. Campbell JP, Karolak MR, Ma Y, Perrien DS, Masood-Campbell SK, Penner NL, Munoz SA, Zijlstra A, Yang X, Sterling JA, Elefteriou F: Stimulation of host bone marrow stromal cells by sympathetic nerves promotes breast cancer bone metastasis in mice. PLoS Biol 2012, 10: e1001363

107. Lutgendorf SK, DeGeest K, Sung CY, Arevalo JM, Penedo F, Lucci J III, Goodheart M, Lubaroff D, Farley DM, Sood AK, Cole SW: Depression, social support, and beta-adrenergic transcription control in human ovarian cancer. Brain Behav Immun 2009, 23: $176-183$
108. Powe DG, Voss MJ, Zanker KS, Habashy HO, Green AR, Ellis IO, Entschladen F: Beta-blocker drug therapy reduces secondary cancer formation in breast cancer and improves cancer specific survival. Oncotarget 2010, 1:628-638

109. Barron TI, Connolly RM, Sharp L, Bennett K, Visvanathan K: Beta blockers and breast cancer mortality: a population-based study. J Clin Oncol 2011, 29:2635-2644

110. Melhem-Bertrandt A, Chavez-Macgregor M, Lei X, Brown EN, Lee RT, Meric-Bernstam F, Sood AK, Conzen SD, Hortobagyi GN, Gonzalez-Angulo AM: Beta-blocker use is associated with improved relapse-free survival in patients with triple-negative breast cancer. J Clin Oncol 2011, 29:2645-2652

111. Jin W, Xu S, Wang H, Yu Y, Shen Y, Wu B, Jin L: Genome-wide detection of natural selection in African Americans pre- and postadmixture. Genome Res 2012, 22:519-527

112. Storey JD, Madeoy J, Strout JL, Wurfel M, Ronald J, Akey JM: Gene-expression variation within and among human populations. Am J Hum Genet 2007, 80:502-509

113. Zhang W, Duan S, Kistner EO, Bleibel WK, Huang RS, Clark TA, Chen TX, Schweitzer AC, Blume JE, Cox NJ, Dolan ME: Evaluation of genetic variation contributing to differences in gene expression between populations. Am J Hum Genet 2008, 82: 631-640

114. Giri VN, Beebe-Dimmer JL: Familial prostate cancer. Semin Oncol 2016, 43:560-565

115. Haiman CA, Chen GK, Blot WJ, Strom SS, Berndt SI, Kittles RA, Rybicki BA, Isaacs WB, Ingles SA, Stanford JL, Diver WR, Witte JS, Chanock SJ, Kolb S, Signorello LB, Yamamura Y, Neslund-Dudas C, Thun MJ, Murphy A, Casey G, Sheng X, Wan P, Pooler LC, Monroe KR, Waters KM, Le ML, Kolonel LN, Stram DO, Henderson BE: Characterizing genetic risk at known prostate cancer susceptibility loci in African Americans. PLoS Genet 2011, 7: e1001387

116. Ahmadiyeh N, Pomerantz MM, Grisanzio C, Herman P, Jia L, Almendro V, He HH, Brown M, Liu XS, Davis M, Caswell JL, Beckwith CA, Hills A, Macconaill L, Coetzee GA, Regan MM, Freedman ML: 8q24 Prostate, breast, and colon cancer risk loci show tissue-specific long-range interaction with MYC. Proc Natl Acad Sci U S A 2010, 107:9742-9746

117. Amundadottir LT, Sulem P, Gudmundsson J, Helgason A, Baker A, Agnarsson BA, et al: A common variant associated with prostate cancer in European and African populations. Nat Genet 2006, 38 : 652-658

118. Haiman CA, Patterson N, Freedman ML, Myers SR, Pike MC, Waliszewska A, Neubauer J, Tandon A, Schirmer C, McDonald GJ, Greenway SC, Stram DO, Le Marchand L, Kolonel LN, Frasco M, Wong D, Pooler LC, Ardlie K, Oakley-Girvan I, Whittemore AS, Cooney KA, John EM, Ingles SA, Altshuler D, Henderson BE, Reich D: Multiple regions within 8q24 independently affect risk for prostate cancer. Nat Genet 2007, 39:638-644

119. Robbins C, Torres JB, Hooker S, Bonilla C, Hernandez W, Candreva A, Ahaghotu C, Kittles R, Carpten J: Confirmation study of prostate cancer risk variants at 8q24 in African Americans identifies a novel risk locus. Genome Res 2007, 17:1717-1722

120. Freedman ML, Haiman CA, Patterson N, McDonald GJ, Tandon A, Waliszewska A, Penney K, Steen RG, Ardlie K, John EM, OakleyGirvan I, Whittemore AS, Cooney KA, Ingles SA, Altshuler D, Henderson BE, Reich D: Admixture mapping identifies 8q24 as a prostate cancer risk locus in African-American men. Proc Natl Acad Sci U S A 2006, 103:14068-14073

121. Haiman CA, Chen GK, Blot WJ, Strom SS, Berndt SI, Kittles RA, et al: Genome-wide association study of prostate cancer in men of African ancestry identifies a susceptibility locus at 17q21. Nat Genet 2011, 43:570-573

122. Berndt SI, Wang Z, Yeager M, Alavanja MC, Albanes D, Amundadottir L, et al: Two susceptibility loci identified for prostate cancer aggressiveness. Nat Commun 2015, 6:6889 
123. Fanale D, Amodeo V, Corsini LR, Rizzo S, Bazan V, Russo A: Breast cancer genome-wide association studies: there is strength in numbers. Oncogene 2012, 31:2121-2128

124. Garcia-Closas M, Couch FJ, Lindstrom S, Michailidou K, Schmidt MK, Brook MN, et al: Genome-wide association studies identify four ER negative-specific breast cancer risk loci. Nat Genet 2013, 45:392-398.e2

125. Purrington KS, Slager S, Eccles D, Yannoukakos D, Fasching PA, Miron P, et al: Genome-wide association study identifies 25 known breast cancer susceptibility loci as risk factors for triple-negative breast cancer. Carcinogenesis 2014, 35:1012-1019

126. Pirie A, Guo Q, Kraft P, Canisius S, Eccles DM, Rahman N, et al: Common germline polymorphisms associated with breast cancerspecific survival. Breast Cancer Res 2015, 17:58

127. Chen F, Stram DO, Le ML, Monroe KR, Kolonel LN, Henderson BE, Haiman CA: Caution in generalizing known genetic risk markers for breast cancer across all ethnic/racial populations. Eur J Hum Genet 2011, 19:243-245

128. Huo D, Zheng Y, Ogundiran TO, Adebamowo C, Nathanson KL, Domchek SM, Rebbeck TR, Simon MS, John EM, Hennis A, Nemesure B, Wu SY, Leske MC, Ambs S, Niu Q, Zhang J, Cox NJ, Olopade OI: Evaluation of 19 susceptibility loci of breast cancer in women of African ancestry. Carcinogenesis 2012, 33:835-840

129. Chen F, Chen GK, Stram DO, Millikan RC, Ambrosone CB, John EM, et al: A genome-wide association study of breast cancer in women of African ancestry. Hum Genet 2013, 132:39-48

130. Feng Y, Stram DO, Rhie SK, Millikan RC, Ambrosone CB, John EM, Bernstein L, Zheng W, Olshan AF, Hu JJ, Ziegler RG, Nyante S, Bandera EV, Ingles SA, Press MF, Deming SL, Rodriguez-Gil JL,
Palmer JR, Olopade OI, Huo D, Adebamowo CA, Ogundiran T, Chen GK, Stram A, Park K, Rand KA, Chanock SJ, Le Marchand L, Kolonel LN, Conti DV, Easton D, Henderson BE, Haiman CA: A comprehensive examination of breast cancer risk loci in African American women. Hum Mol Genet 2014, 23:5518-5526

131. Huo D, Feng Y, Haddad S, Zheng Y, Yao S, Han YJ, et al: Genomewide association studies in women of African ancestry identified $3 q 26.21$ as a novel susceptibility locus for oestrogen receptor negative breast cancer. Hum Mol Genet 2016, 25:4835-4846

132. Haiman CA, Chen GK, Vachon CM, Canzian F, Dunning A, Millikan RC, et al: A common variant at the TERT-CLPTM1L locus is associated with estrogen receptor-negative breast cancer. Nat Genet 2011, 43:1210-1214

133. Fejerman L, John EM, Huntsman S, Beckman K, Choudhry S, PerezStable E, Burchard EG, Ziv E: Genetic ancestry and risk of breast cancer among U.S. Latinas. Cancer Res 2008, 68:9723-9728

134. Ruiz-Narvaez EA, Sucheston-Campbell L, Bensen JT, Yao S, Haddad S, Haiman CA, Bandera EV, John EM, Bernstein L, Hu JJ, Ziegler RG, Deming SL, Olshan AF, Ambrosone CB, Palmer JR, Lunetta KL: Admixture mapping of African-American women in the AMBER Consortium identifies new loci for breast cancer and estrogen-receptor subtypes. Front Genet 2016, 7:170

135. Prueitt RL, Wallace TA, Glynn SA, Yi M, Tang W, Luo J, Dorsey TH, Stagliano KE, Gillespie JW, Hudson RS, Terunuma A, Shoe JL, Haines DC, Yfantis HG, Han M, Martin DN, Jordan SV, Borin JF, Naslund MJ, Alexander RB, Stephens RM, Loffredo CA, Lee DH, Putluri N, Sreekumar A, Hurwitz AA, Ambs S: An immuneinflammation gene expression signature in prostate tumors of smokers. Cancer Res 2016, 76:1055-1065 